http://jmscr.igmpublication.org/home/ ISSN (e)-2347-176x ISSN (p) 2455-0450 crossref DOI: https://dx.doi.org/10.18535/jmscr/v8i5.33

Original Research Article

\title{
Prevalence of lipid profile derangement in previously diagnosed treatment naive cases of Subclinical Hypothyroid patients and its comparison with age and sex matched normal individuals: A case control study at tertiary health care centre from central India
}

\author{
Authors \\ Dr Rajesh Verma ${ }^{1}$, Dr Yogesh Yadav ${ }^{2 *}$, Dr Sumit Kumar Vishwakarma ${ }^{3}$ \\ ${ }^{1}$ DM Endocrinology, Associate Professor, Department of Medicine, MY Hospital and MGM Medical \\ College, Indore, MP \\ ${ }^{2}$ MD Medicine, Former Resident, Department of Medicine, MY Hospital and MGM Medical College, \\ Indore, MP \\ ${ }^{3}$ PG Resident, Department of Medicine, MY Hospital and MGM Medical College, Indore, MP \\ *Corresponding Author \\ Dr Yogesh Yadav
}

\begin{abstract}
Background: Clinical significance of Sub-Clinical Hypothyroidism (SCH) is because of its high prevalence, risk of progression to overt hypothyroidism $(\mathrm{OH})$, serious complications like neurobehavioral and cardiovascular disorders and poor quality of life because of non-specific symptoms. Cardiovascular complications occur in these patients is because of un-favorable lipid profile.

Methods: This prospective observational study was carried out in the Department of Medicine MGM Medical College and MY Hospital Indore from January 2017 to June 2018 enrolling total 100 patients.

Results: In normal subject, the mean total cholesterol was $125.92 \pm 43.38 \mathrm{mg} / \mathrm{dl}$, in SCH patients it was $117.14 \pm 39.33 \mathrm{mg} / \mathrm{dl}$, showing a higher mean total cholesterol in SCH patients as compared to normal subjects, and the difference came out to be statistically significant $(P<0.05)$. In normal subject, the mean triglyceride was $80.72 \pm 13.03 \mathrm{mg} / \mathrm{dl}$, in $\mathrm{SCH}$ patients it was $123 \pm 74.34 \mathrm{mg} / \mathrm{dl}$, showing a higher mean triglycerides in SCH patients as compared to normal subjects and the difference was found to be statistically significant $(P<0.05)$. In normal subject, the VLDL was $16.12 \pm 2.72 \mathrm{mg} / \mathrm{dl}$, in SCH patients it was $26.05 \pm 16.80 \mathrm{mg} / \mathrm{dl}$, showing a higher mean VLDL in SCH patients as compared to normal subjects. The difference was statistically significant $(P<0.05)$.

Conclusions: SCH is associated with slight increase in TC, TG, VLDL, and LDL levels and decrease in $H D L$. Increased TC, TG, VLDL, and LDL in high normal range and decreased HDL in low normal range indicating trend towards atherogenic lipid profile. Thus SCH is associated with increased cardiovascular risk due lipid profile derangements.

Keywords: Cholesterol, subclinical hypothyroidism, overt hypothyroidism, triglyceride.
\end{abstract}




\section{Introduction}

Marginal elevation $(5.3-10 \mathrm{mIU} / \mathrm{ml})$ of serum $\mathrm{TSH}$ in the presence of normal free $\mathrm{T}_{4}$ levels $(0.7$ $2.5 \mathrm{ng} / \mathrm{dl}$ ) is called as Subclinical Hypothyroidism $(\mathrm{SCH})$ or mild thyroid failure. This term is only applicable when the hypothalamic-pituitarythyroid axis is normal, there is no recent or ongoing severe illness, and thyroid function has been stable for weeks or more. ${ }^{[1]}$

One of the commonest endocrine conditions occurring in about 4 to $10 \%$ population. The prevalence increases with age and is more common in women. Clinical significance of $\mathrm{SCH}$ is because of its high prevalence, risk of progression to overt hypothyroidism $(\mathrm{OH})$, serious complications like neurobehavioral and cardiovascular disorders and poor quality of life because of non-specific symptoms. Cardiovascular complications occur in these patients is because of unfavourable lipid profile. Thyroid hormones have varied effects on lipid metabolism, as they regulate lipids synthesis and degradation, by regulating the activity of key enzymes in these pathways. An elevated TSH, usually above $10 \mathrm{mIU} / \mathrm{l}$ in combination with a subnormal free $\mathrm{T}_{4}$ characterizes $\mathrm{OH}$. The association between $\mathrm{OH}$ and dyslipidemia is well known which predispose to cardiovascular complications however association of $\mathrm{SCH}$ with lipid profile derangements is uncertain. Various studies conducted on this relationship, have variable results. In this respect, it has been postulated that Hypothyroidism is associated with suppression of both synthesis and degradation of lipids with greater 2 reduction in degradation ultimately resulting in accumulation of Low density lipoproteins (LDL-C) and triglycerides (TG). Reduced Lipid degradation may be because of decrease in post heparin lipolytic activity, as well as reduced LDL receptors.

\section{Methods}

This study was carried out in the Department of Medicine MGM Medical College and MY Hospital Indore from January 2017 to June 2018 enrolling total 100 subjects, out of which 50 patients were of SCH not taking any treatment and 50 were normal subjects coming with patients to the OPD or wards in MY Hospital, Indore, MP.

\section{Inclusion Criteria}

1. Already diagnosed and treatment naive SCH patients based on TSH level between 5-10 micro IU/ml and normal free $\mathrm{T} 4$ value $0.7-2.5 \mathrm{ng} / \mathrm{dl}$.

2. Age and sex matched already diagnosed treatment naive patients of overt hypothyroidism.

3. Age and sex matched normal subjects giving consent.

4. Patients 30-60 years of age who give consent.

\section{Exclusion Criteria}

1. Patients receiving drugs which are known to cause $\mathrm{SCH}$ and affect lipid metabolism.

2. Patient on treatment for hypothyroidism.

3. Patients with systemic diseases like Diabetes mellitus, PCOD, Renal and Hepatic failure, Stroke, ischemic heart disease, primary or secondary dyslipidemia, pregnant women and substance abusers.

4. Patients not giving consent for the study.

5. Patients $<30$ years and $>60$ years.

\section{Sample Size}

Total 100 patients and 50 normal controls, 50 of $\mathrm{SCH}$ and 50 of overt Hypothyroidism not taking treatment and 50 age and sex matched individuals who were the caretakers of patients coming to $\mathrm{MYH}$, Indore.

\section{Duration of Study}

2 Years from day of approval. Patients and their caregivers were explained about the study in details verbally and by means of a patient information sheet written in simple understandable language. After applying inclusion and exclusion criteria, selected patients from OPD, were enrolled after taking consent to take part in the study. A brief history was taken and 
patient's vitals were taken. Routine investigations like complete blood counts, sodium, potassium, renal function test, liver function test, lipid profiles, thyroid functions, and free $\mathrm{T}_{4}$ were done.

\section{Data Analysis}

Data analysis was done using SPSS software.

\section{Results}

This study was carried out in the Department of Medicine MGM Medical College and MY Hospital Indore from January 2017 to June 2018 enrolling total 100 subjects, out of which 50 patients were of SCH not taking any treatment and 50 were normal subjects coming with patients to the OPD or wards in MY Hospital. Results of this study were as follows:

As shown in table 1 , in our study of total 100 patients there were $85(85.0 \%)$ females and 15 (15.0\%) males showing a female preponderance. As shown in table 2, there were $60(60 \%$ ) patients in the age group 30-40 years, $25(25 \%)$ were in the age group $41-50$ years, $15(15 \%)$ were in the age group 51-60 years. Majority of the patients were in the age group 30-40 years.

Table 1: Distribution of patients according to gender

\begin{tabular}{|l|c|c|c|c|c|c|}
\hline \multirow{2}{*}{ Gender } & \multicolumn{2}{|c|}{ Normal Subjects } & Subclinical Hypothyroidism & \multicolumn{2}{c|}{ Total } \\
\cline { 2 - 7 } & Number & $\%$ & Number & $\%$ & Number & $\%$ \\
\hline Female & 42 & $\mathbf{8 4}$ & $\mathbf{4 3}$ & $\mathbf{8 6}$ & $\mathbf{8 5}$ & $\mathbf{8 5}$ \\
\hline Male & $\mathbf{8}$ & 16 & 7 & 14 & 15 & 15 \\
\hline Total & $\mathbf{5 0}$ & $\mathbf{1 0 0}$ & $\mathbf{5 0}$ & $\mathbf{1 0 0}$ & 100 & 100 \\
\hline
\end{tabular}

Table 2: Distribution of patients according to age group

\begin{tabular}{|l|c|c|c|c|c|c|}
\hline \multirow{2}{*}{$\begin{array}{l}\text { Age Group } \\
\text { In Years }\end{array}$} & \multicolumn{2}{|c|}{ Normal Subjects } & \multicolumn{2}{c|}{ Subclinical Hypothyroidism } & \multicolumn{2}{c|}{ Total } \\
\cline { 2 - 7 } & Number & $\%$ & Number & $\%$ & Number & $\%$ \\
\hline $30-40$ & 31 & 62 & 29 & 58 & 60 & 60 \\
\hline $41-50$ & 12 & 24 & 13 & 26 & 25 & 25 \\
\hline $51-60$ & 7 & 14 & 8 & 16 & 15 & 15 \\
\hline Total & 50 & 100 & 50 & 100 & 100 & 100 \\
\hline
\end{tabular}

As shown in table 3, comparison of various lipid parameters in between normal and $\mathrm{SCH}$. In normal subject, the mean total cholesterol(TC) was $125.92 \pm 43.38 \mathrm{mg} / \mathrm{dl}$ and in $\mathrm{SCH}$ patients it was $117.14 \pm 39.33 \mathrm{mg} / \mathrm{dl}$, showing a higher mean $\mathrm{TC}$ in $\mathrm{SCH}$ patients as compared to normal subjects, and the difference came out to be statistically significant $\quad(\mathrm{P}<0.05)$. Mean triglyceride (TG) levels was $80.72 \pm 13.03 \mathrm{mg} / \mathrm{dl}$ in normal subjects, and it was $123 \pm 74.34 \mathrm{mg} / \mathrm{dl}$ in $\mathrm{SCH}$ patients, showing a higher mean TG in $\mathrm{SCH}$ patients as compared to normal subjects and the difference was found to be statistically significant $(\mathrm{P}<0.05)$. The very low density lipoprotein (VLDL) was $16.12 \pm 2.72 \mathrm{mg} / \mathrm{dl}$ in normal subjects, and it was $26.05 \pm 16.80 \mathrm{mg} / \mathrm{dl}$ in $\mathrm{SCH}$ patients, showing a higher mean VLDL in SCH patients as compared to normal subjects. The difference was statistically significant $(\mathrm{P}<0.05)$. In normal subject, the Low density lipoprotein(LDL) was $60.21 \pm 7.80 \mathrm{mg} / \mathrm{dl}$, and in $\mathrm{SCH}$ patients it was $78.88 \pm 31.21 \mathrm{mg} / \mathrm{dl}$ showing a higher mean LDL in $\mathrm{SCH}$ patients as compared to normal subjects and the difference came out to be statistically significant $(\mathrm{P}<0.05)$. In normal subject, the high density lipoprotein(HDL) was $49.39 \pm 4.52 \mathrm{mg} / \mathrm{dl}$, in $\mathrm{SCH}$ patients it was $45.32 \pm 15.4 \mathrm{mg} / \mathrm{dl}$, showing a lower mean HDL in SCH patients as compared to normal subjects and the difference came out to be statistically not significant $(\mathrm{P}>0.05)$. 
Table 3: Comparison of various lipid parameters in between controls and subclinical hypothyroidism patients

\begin{tabular}{|c|c|c|c|c|}
\hline Characteristics & Controls & $\begin{array}{c}\text { Subclinical } \\
\text { Hypothyroidism }\end{array}$ & 't' value & P value \\
\hline $\begin{array}{l}\text { Total Cholesterol in } \\
\mathrm{mg} / \mathrm{dl}(\mathrm{mean} \pm \mathrm{SD})\end{array}$ & $100.24 \pm 12.54$ & $149.04 \pm 38.30$ & $-8.560, \mathrm{df}=98$ & 0.000 \\
\hline $\begin{array}{l}\text { Triglycerides } \\
\text { mg/dl (mean } \pm \text { SD) }\end{array}$ & $80.72 \pm 13.03$ & $123 \pm 74.34$ & $-3.96, d f=98$ & 0.000 \\
\hline $\begin{array}{l}\text { VLDL in } \mathrm{mg} / \mathrm{dl} \\
(\text { Mean } \pm \mathrm{SD})\end{array}$ & $16.12 \pm 2.72$ & $26.05 \pm 16.80$ & $-4.125, \mathrm{df}=98$ & 0.000 \\
\hline $\begin{array}{l}\text { LDL in mg/dl } \\
(\text { Mean } \pm \text { SD) }\end{array}$ & $60.21 \pm 7.80$ & $78.88 \pm 31.21$ & $-4.10, \mathrm{df}=98$ & 0.000 \\
\hline $\begin{array}{l}\text { HDL in mg/dl } \\
(\text { mean } \pm \text { SD) }\end{array}$ & $49.39 \pm 4.52$ & $45.32 \pm 15.4$ & $1.78, \mathrm{df}=98$ & 0.77 \\
\hline
\end{tabular}

\section{Discussion}

In our study, there were $65(65 \%)$ patients in the age group 30-40 years, 25 (25\%) patients in age group 41-50 years, and $15(15 \%)$ patients in age group 51-60 years. Majority of the patients were in the age group 30-40 years. Study done by Bayar Qasim et al $^{[2]}$ also showed that majority of the patients were in age group 30-39 years.

In our study, out of total 100 patients and 50 controls, $85(85 \%)$ were females and $15(15 \%)$ were males. Hence there was female preponderance in our study. Study done by Zoe Efstathiadou et $\mathrm{al}^{[3]}$ found male-female ratio of $1: 12$, Mounika Guntaka et $\mathrm{al}^{[4]}$ found malefemale ratio of 1:9. These studies suggest female preponderance of thyroid disease like our study.

Lipid Profile Analysis: In our study, the mean TC levels, mean TG levels, mean LDL levels and mean VLDL levels were found to be significantly raised in patients of subclinical as compared to normal controls $(\mathrm{P}<0.05)$. Mean HDL levels were found to be decreased in subclinical hypothyroidism patients as compared to normal subjects but this difference was statistically non significant $(\mathrm{P}>0.05)$. Study conducted by Shashi $\mathrm{A}$ et $\mathrm{al}^{[5]}$ exhibited a significantly higher concentration of $\mathrm{TC}(\mathrm{P}<0.0001), \mathrm{TG}(\mathrm{P}<0.0001)$, LDL $(\mathrm{P}<0.0001)$ significantly lower concentration of $\mathrm{HDL}(\mathrm{P}<0.0001)$ in $\mathrm{SCH}$ patients as compared to euthyroid controls and these results were similar to our study.

\section{Conclusions}

Subclinical hypothyroidism is associated with increase in TC, TG, VLDL and LDL levels and decrease in HDL. Increased TC, TG, VLDL and LDL in high normal range and decreased HDL in low normal range indicating trend towards atherogenic lipid profile. Thus Subclinical hypothyroidism is associated with increased cardiovascular risk due lipid profile derangements.

\section{Disclosure}

Funding: No funding sources

Conflict of interest: Not declared

Ethical approval: The study was approved by the Institutional Ethics Committee

\section{References}

1. ATA/AACE Guidelines for Hypothyroidism in adults, Endocr Pract. 2012:18: 6: 989.

2. Bayar Qasim, Sardar Arif, Ayad Mohammed and Rezvan Abduljabbar. Dyslipidemia in Subclinical Hypothyroidism: A Case-Control Study. J Endocrinol Diab. 2018; 5:1: 16.

3. Zoe Efstathiadou, Spiridon Bitsis, Haralampos J Milionis, Asterios Kukuvitis, Eleni T Bairaktari, Moses S Elisaf et al. Lipid profile in subclinical hypothyroidism: is L-thyroxine substitution beneficial? Europian journal of Endocrinology. 2001; 145: 6: 705-10. 
4. Mounika Guntaka, Babulreddy Hanmayyagari, Manne Rosaline, Nagesh V. Lipid profile in subclinical hypothyroidism: A biochemical study from tertiary care hospital. CHRISMED Journal of Health and Research. 2014; 1: 4: 266-270.

5. Shashi A, Sharma N, Lipid profile abnormalities in hypothyroidism. I.J.S.N. 2012; 3: 2: 354-360. 